\title{
Th2 cytokine bias induced by silver nanoparticles in peripheral blood mononuclear cells of common bottlenose dolphins (Tursiops truncatus)
}

\author{
Wen-Ta Li ${ }^{1}$, Lei-Ya Wang ${ }^{1}$, Hui-Wen Chang ${ }^{1}$, Wei-Cheng Yang ${ }^{2}$, Chieh Lo ${ }^{3}$, Victor Fei Pang ${ }^{1}$, Meng- \\ Hsien Chen ${ }^{4}$, Chian-Ren Jeng ${ }^{\text {Corresp. } 1}$ \\ ${ }^{1}$ Graduate Institute of Molecular and Comparative Pathobiology, National Taiwan University, Taipei, Taiwan \\ 2 College of Veterinary Medicine, National Chiayi University, Chiayi, Taiwan \\ 3 Farglory Ocean Park, Hualien, Taiwan \\ 4 Department of Oceanography and Asia-Pacific Ocean Research Center, National Sun Yat-Sen University, Kaohsiung, Taiwan \\ Corresponding Author: Chian-Ren Jeng \\ Email address: crjeng@ntu.edu.tw
}

Background Silver nanoparticles (AgNPs) have been widely used in many commercial products due to their excellent antibacterial ability. The AgNPs are released into the environment, gradually accumulate in the ocean, and may affect animals at high trophic level, such as cetaceans and humans, via the food chain. Hence, the negative health impacts caused by AgNPs in cetaceans are of concern. Cytokines play a major role in the modulation of immune system and can be classified into two types, Th1 and Th2. Th1/Th2 balance can be evaluated by the ratios of their polarizing cytokines (i.e., interferon [IFN]-Y/ Interleukin [IL]-4), and animals with imbalanced Th1/Th2 response may become more susceptible to certain kinds of infection. Therefore, the present study evaluated the in vitro cytokine responses of cetacean peripheral blood mononuclear cells (cPBMCs) to $20 \mathrm{~nm}$ citrate-AgNPs (C-AgNP ${ }_{20}$ ) by quantitative reverse transcriptase polymerase chain reaction (qRT-PCR).

Methods Blood samples were collected from 6 captive common bottlenose dolphins (Tursiops truncatus). The cPBMCs were isolated and utilized for evaluating the in vitro cytokine responses. The cytokines evaluated included IL-2, IL-4, IL-10, IL-12, interferon (IFN)- $\gamma$, and tumor necrosis factor (TNF)-a. The geometric means of two housekeeping genes (HKGs), glyceraldehyde 3-phosphate dehydrogenase (GAPDH) and $\beta 2$-microglobulin (B2M), of each sample were determined and used to normalize the mRNA expression levels of target genes.

Results The ratio of late apoptotic/necrotic cells of cPBMCs significantly increased with or without concanavalin A (ConA) stimulation after $24 \mathrm{~h}$ of $10 \mu \mathrm{g} / \mathrm{ml} \mathrm{C-AgNP}{ }_{20}$ treatment. At $4 \mathrm{~h}$ of culture, the mRNA

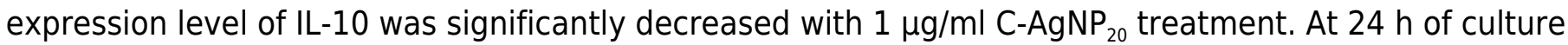
with $1 \mu \mathrm{g} / \mathrm{ml} \mathrm{C}-\mathrm{AgNP}_{20}$, the mRNA expression levels of all cytokines were significantly decreased, with the exceptions of IL-4 and IL-10. The IFN-y/IL-4 ratio was significantly decreased at $24 \mathrm{~h}$ of culture with 1 $\mu \mathrm{g} / \mathrm{ml} \mathrm{C}-\mathrm{AgNP}_{20}$ treatment, and the IL-12/IL-4 ratio was significantly decreased at 4 or $24 \mathrm{~h}$ of culture with 0.1 or $1 \mu \mathrm{g} / \mathrm{ml} \mathrm{C-AgNP}{ }_{20}$ treatment, respectively. Furthermore, the mRNA expression level of TNF- $\alpha$ was significantly decreased by $1 \mu \mathrm{g} / \mathrm{ml} \mathrm{C}-\mathrm{AgNP}_{20}$ after $24 \mathrm{~h}$ of culture.

Discussion The present study demonstrated that the sublethal dose of C-AgNP20 ( $\leq 1 \mu \mathrm{g} / \mathrm{ml}$ ) had an inhibitory effect on the cytokine mRNA expression levels of cPBMCs with the evidence of Th2 cytokine bias and significantly decreased the mRNA expression level of TNF- $\alpha$. Th2 cytokine bias is associated with enhanced immunity against parasites but decreased immunity to intracellular microorganisms. TNF- $\alpha$ is a contributing factor for the inflammatory response against the infection of intracellular pathogens. In 
summary, our data indicate that $\mathrm{C}-\mathrm{AgNP}_{20}$ suppresses the cellular immune response and thereby increases the susceptibility of cetaceans to infection by intracellular microorganisms. 


\section{Th2 cytokine bias induced by silver nanoparticles in}

\section{2 peripheral blood mononuclear cells of common bottlenose}

\section{3 dolphins (Tursiops truncatus)}

4 Wen-Ta Li ${ }^{1}$, Lei-Ya Wang', Hui-Wen Chang1, Wei-Cheng Yang ${ }^{2}$, Chieh Lo ${ }^{3}$, Victor Fei

$5 \quad$ Pang $^{1}$, Meng-Hsien Chen ${ }^{4}$, Chian-Ren Jeng1

$6{ }^{1}$ Graduate Institute of Molecular and Comparative Pathobiology, National Taiwan University,

7 Taipei 10617, Taiwan

$8{ }^{2}$ College of Veterinary Medicine, National Chiayi University, Chiayi 60004, Taiwan; Current

9 Address: School of Veterinary Medicine, National Taiwan University, Taipei 10617, Taiwan

$10{ }^{3}$ Farglory Ocean Park, Hualien 97449, Taiwan

$11{ }^{4}$ Department of Oceanography and Asia-Pacific Ocean Research Center, National Sun Yat-sen

12 University, Kaohsiung 80424, Taiwan

14 Corresponding author:

15 Chian-Ren Jeng ${ }^{1}$

16 No. 1, Sec. 4, Roosevelt Rd., Taipei 10617, Taiwan

17 Email address: crjeng@ntu.edu.tw 


\section{Abstract}

\section{Background}

21 Silver nanoparticles (AgNPs) have been widely used in many commercial products due to their

22 excellent antibacterial ability. The AgNPs are released into the environment, gradually

23 accumulate in the ocean, and may affect animals at high trophic level, such as cetaceans and

24 humans, via the food chain. Hence, the negative health impacts caused by AgNPs in cetaceans

25 are of concern. Cytokines play a major role in the modulation of immune system and can be

26 classified into two types, Th1 and Th2. Th1/Th2 balance can be evaluated by the ratios of their

27 polarizing cytokines (i.e., interferon [IFN]- $\gamma /$ Interleukin [IL]-4), and animals with imbalanced

28 Th1/Th2 response may become more susceptible to certain kinds of infection. Therefore, the

29 present study evaluated the in vitro cytokine responses of cetacean peripheral blood mononuclear

30 cells (cPBMCs) to $20 \mathrm{~nm}$ citrate-AgNPs $\left(\mathrm{C}-\mathrm{AgNP}_{20}\right)$ by quantitative reverse transcriptase

31 polymerase chain reaction (qRT-PCR).

\section{Methods}

33 Blood samples were collected from 6 captive common bottlenose dolphins (Tursiops truncatus).

34 The cPBMCs were isolated and utilized for evaluating the in vitro cytokine responses. The

35 cytokines evaluated included IL-2, IL-4, IL-10, IL-12, interferon (IFN)- $\gamma$, and tumor necrosis

36 factor (TNF)-a. The geometric means of two housekeeping genes (HKGs), glyceraldehyde 3- 
37 phosphate dehydrogenase (GAPDH) and $\beta 2$-microglobulin (B2M), of each sample were

38 determined and used to normalize the mRNA expression levels of target genes.

\section{Results}

40 The ratio of late apoptotic/necrotic cells of cPBMCs significantly increased with or without

41 concanavalin A (ConA) stimulation after $24 \mathrm{~h}$ of $10 \mu \mathrm{g} / \mathrm{ml} \mathrm{C-AgNP} 20$ treatment. At $4 \mathrm{~h}$ of

42 culture, the mRNA expression level of IL-10 was significantly decreased with $1 \mu \mathrm{g} / \mathrm{ml} \mathrm{C}$ -

$43 \mathrm{AgNP}_{20}$ treatment. At $24 \mathrm{~h}$ of culture with $1 \mu \mathrm{g} / \mathrm{ml} \mathrm{C-AgNP}{ }_{20}$, the mRNA expression levels of all

44 cytokines were significantly decreased, with the exceptions of IL-4 and IL-10. The IFN- $\gamma /$ IL-4

45 ratio was significantly decreased at $24 \mathrm{~h}$ of culture with $1 \mu \mathrm{g} / \mathrm{ml} \mathrm{C}-\mathrm{AgNP}_{20}$ treatment, and the IL-

$4612 / \mathrm{IL}-4$ ratio was significantly decreased at 4 or $24 \mathrm{~h}$ of culture with 0.1 or $1 \mu \mathrm{g} / \mathrm{ml} \mathrm{C-AgNP} 20$

47 treatment, respectively. Furthermore, the mRNA expression level of TNF- $\alpha$ was significantly

48 decreased by $1 \mu \mathrm{g} / \mathrm{ml} \mathrm{C}-\mathrm{AgNP}_{20}$ after $24 \mathrm{~h}$ of culture.

\section{Discussion}

50 The present study demonstrated that the sublethal dose of C-AgNP20 $(\leq 1 \mu \mathrm{g} / \mathrm{ml})$ had an

51 inhibitory effect on the cytokine mRNA expression levels of cPBMCs with the evidence of Th2

52 cytokine bias and significantly decreased the mRNA expression level of TNF- $\alpha$. Th2 cytokine

53 bias is associated with enhanced immunity against parasites but decreased immunity to

54 intracellular microorganisms. TNF- $\alpha$ is a contributing factor for the inflammatory response 
55 against the infection of intracellular pathogens. In summary, our data indicate that $\mathrm{C}-\mathrm{AgNP} \mathrm{P}_{20}$

56 suppresses the cellular immune response and thereby increases the susceptibility of cetaceans to

57 infection by intracellular microorganisms. 


\section{Introduction}

60 The application of silver nanoparticles (AgNPs) in industry and in consumer products has

61 increased, and the production of AgNPs and the number of AgNP-containing products will

62 increase over time (Massarsky et al. 2014). AgNPs can be released during the production,

63 transport, decay, use, and/or disposal of AgNP-containing products, subsequently draining into

64 the surface water and then accumulating in the marine environment (Farre et al. 2009; Walters et

65 al. 2014). Therefore, the increasing use and growing production of AgNPs, as potential sources

66 of Ag contamination, raise public concerns about the environmental toxicity of Ag (Li et al.

67 2018a). Previous research has demonstrated that AgNPs can precipitate in marine sediments, be

68 ingested by benthic organisms (such as benthic invertebrate species), enter and be transferred

69 from one trophic level to the next via the food chain, and thereby cause negative effects on the

70 animals at different trophic levels, such as algae, invertebrates and fishes (Buffet et al. 2014;

71 Farre et al. 2009; Gambardella et al. 2015; Huang et al. 2016b; Wang et al. 2014). Previous

72 studies have demonstrated that AgNPs are toxic to all tested marine organisms in a dose-

73 dependent manner, indicating that AgNPs may have negative effects on marine organisms at

74 different trophic levels of the marine environment. Immunotoxic effects of AgNPs have been

75 demonstrated in some aquatic animals such as Nile tilapia and mussel (Gagne et al. 2013; 
76 Thummabancha et al. 2016). Nevertheless, to date the potential toxicity of AgNPs on marine

77 mammals such as cetaceans has not been sufficiently studied.

78 AgNPs have been demonstrated to cause several negative effects, such as hepatitis,

79 nephritis, neuron cell apoptosis, and alteration of gene expression of the brain, on laboratory

80 mammals (Espinosa-Cristobal et al. 2013; Sardari et al. 2012; Shahare \& Yashpal 2013). In vitro

81 studies using different cell lines have also indicated that AgNPs can cause damage to DNA, cell

82 membranes, and mitochondria through reactive oxygen species (ROS) dependent/independent

83 pathways and further induce cytotoxicity and genotoxicity (Kim \& Ryu 2013). In addition,

84 previous studies conducted in laboratory mammals, including mice and rats, have demonstrated

85 that AgNPs can enter the blood circulation through alimentary tracts and then deposit in multiple

86 organs (Espinosa-Cristobal et al. 2013; Lee et al. 2013; Shahare \& Yashpal 2013; van der Zande

87 et al. 2012). Considering the negative effects of AgNPs and the presence of AgNPs in blood

88 circulation, the negative effects of AgNPs on leukocytes should be of concern. Previous studies

89 have demonstrated that AgNPs can cause several negative effects on human polymorphonuclear

90 leukocytes (PMNs) and peripheral blood mononuclear cells (PBMCs). These studies

91 demonstrated that AgNPs could cause morphological alterations, cytotoxicity, atypical cell

92 death, inhibition of de novo protein synthesis, increased production of the CXCL8 chemokine

93 (IL-8), and impaired lysosomal activity in human neutrophils (Poirier et al. 2014; Poirier et al. 
94 2016; Soares et al. 2016). Only a few studies have investigated the toxicity of AgNPs on human

95 PBMCs, which have shown that AgNPs can cause cytotoxicity and functional perturbations,

96 including inhibition of proliferative activity and cytokine production (Franco-Molina et al. 2016;

97 Ghosh et al. 2012; Huang et al. 2016a; Orta-Garcia et al. 2015; Paino \& Zucolotto 2015; Shin et

98 al. 2007).

99 The environmental contamination level of AgNPs is expected to increase greatly in the near

100 future, and cetaceans, as the top predators in the ocean, will suffer the potentially negative

101 impacts caused by AgNPs. Besides, immunotoxic effects of AgNPs have been demonstrated

102 previously in humans and aquatic animals. Therefore, it is crucial to investigate the immunotoxic

103 effects caused by AgNPs in cetaceans. Generally, in vivo experiments are rarely feasible, and the

104 ethical issues concerning the study of immunotoxic effects caused by environmental

105 contaminants in cetaceans are difficult to overcome, so in vitro study using blood samples from

106 captive cetaceans would be a logical and crucial approach (Beineke et al. 2010; Desforges et al.

107 2016). Cytokines play a major role in the modulation of the immune system, including

108 lymphocyte proliferation/differentiation, lymphoid development, cell trafficking, and

109 inflammatory response through the interactions between the cytokines themselves and the

110 surface receptors of many different cells (Owen et al. 2013; Tizard 2013a). Previous studies have

111 found that the sequence homology of cytokines among terrestrial and aquatic mammals is low, 
112 but conserved molecule regions can still be found on biologically active areas in marine

113 mammals, such as the receptor binding sites of cytokines, suggesting a conserved biological

114 activity of cytokines in both terrestrial and aquatic mammal species (Beineke et al. 2004;

115 Beineke et al. 2010). Therefore, the functions of cytokines on the immune system in cetaceans

116 may be similar to those in mice and humans. Cytokines can be classified into two groups, Th1

117 and Th2, and their secretion pattern is associated with the balance of Th1 and Th2 responses

118 (Kidd 2003; Owen et al. 2013; Tizard 2013b). Th1 response promotes cell-mediated immune

119 response and thus enhances the immunity against intracellular microorganisms, such as

120 Toxoplasma gondii and Brucella spp., and a variety of viruses. In contrast, Th2 response is

121 associated with enhanced immunity against parasites but decreased immunity to intracellular

122 microorganisms (Owen et al. 2013; Tizard 2013b). The Th1/Th2 balance can be evaluated by the

123 ratios of their polarizing cytokines (i.e., interferon [IFN]- $\gamma /$ interleukin [IL]-4), and animals with

124 imbalanced Th1/Th2 response (Th1/Th2 polarization) may become more susceptible to certain

125 kinds of infection (Owen et al. 2013; Raphael et al. 2015; Tizard 2013b).

126 Cytokine profiling is still a relatively new field of immunotoxicology in cetaceans, and thus

127 the enzyme-linked immunosorbent assay (ELISA) kit is not widely used for cytokine profiling in

128 cetaceans (Desforges et al. 2016). Hence, it is more feasible to study the cytokine profiling by

129 molecular biology (i.e., quantitative reverse transcriptase polymerase chain reaction; qRT-PCR). 
130 Therefore, the present study evaluates the in vitro cytokine responses of cPBMCs to C-AgNP 20

131 by qRT-PCR. The cytokines measured were as follows: polarizing cytokines of Th1 (IL-12 and

132 IFN- $\gamma$ ) and Th2 (IL-4), and some pro- and anti-inflammatory cytokines (IL-2, IL-10, and tumor

133 necrosis factor $[\mathrm{TNF}]-\mathrm{a})$.

\section{Materials and methods}

\section{AgNPs characterization}

136 Considering the extensive use of $20 \mathrm{~nm}$ citrate-AgNPs $\left(\mathrm{C}-\mathrm{AgNP}_{20}\right)$ in recently reported

137 studies of cetacean and human blood cells (Huang et al. 2016a; Li et al. 2018b; Poirier et al.

138 2014; Poirier et al. 2016), commercial C-AgNP $20\left(\right.$ Pelco $^{\circledR}$ citrate Biopure ${ }^{\mathrm{TM}}$ silver; Ted Pella,

139 CA, USA) was chosen. The C-AgNP 20 had been extensively washed (without centrifugation) so

140 that the level of trace elements becomes less than $0.000001 \%$. Transmission electron microscopy

141 (TEM) for determining surface area and size/shape distributions, UV-visible spectroscopy for

142 measuring the optical properties, particle hydrodynamic diameter and zeta potential, and

143 dynamic light scattering (DLS) for determining the size distribution were performed according to

144 the manufacturer's instructions and previous studies (Poirier et al. 2014; Poirier et al. 2016). The

145 endotoxin level of $\mathrm{C}-\mathrm{AgNP}_{20}$ suspension was examined by ToxinSensor ${ }^{\mathrm{TM}}$ Single Test Kit

146 (GenScript, NJ, USA), and it was lower than or equal to $0.015 \mathrm{EU} / \mathrm{ml}$. For characterization, the

$147 \mathrm{C}-\mathrm{AgNP}_{20}$ obtained from the manufacturer were suspended in complete RPMI-1640 medium 
148 (RPMI-1640 [Gibco, NY, USA] with 10\% fetal bovine serum, 2mM L-glutamine, 50 IU

149 penicillin, and $50 \mu \mathrm{g}$ streptomycin) at a concentration of $50 \mu \mathrm{g} / \mathrm{ml}$, and then examined using a

150 JEM-1400 (JEOL, Japan) TEM. The size distribution and zeta potential of the C-AgNP 20 were

151 determined through Zetasizer Nano-ZS (Malvern Instruments Inc., MA, USA) (Table 1).

152 Measurements were performed by using 100 and $500 \mu \mathrm{g} / \mathrm{ml} \mathrm{C}-\mathrm{AgNP}_{20}$ in $2 \mathrm{mM}$ citrate buffer

153 (pH 7.4). The C-AgNP 20 were diluted to 1,10 , and $100 \mu \mathrm{g} / \mathrm{ml}$ with $2 \mathrm{mM}$ citrate buffer and

154 instantly used for subsequent experiments. Two mM citrate buffer was used as a vehicle control

$155\left(0 \mu \mathrm{g} / \mathrm{ml} \mathrm{C}-\mathrm{AgNP}_{20}\right)$.

\section{Animals and blood sample collection}

157 All procedures involving animals were conducted in accordance with international

158 guidelines, and the protocol had been reviewed and approved by the Council of Agriculture of

159 Taiwan (Approval number 1051700175). Voluntary blood samples were obtained from six

160 clinically healthy bottlenose dolphins (Tursiops truncatus) with confirmation by physical

161 examination, complete blood count, and biochemistry on a monthly basis from 2015 to 2017 at

162 Farglory Ocean Park. Forty millilitres of heparin-anticoagulated whole blood were collected,

163 stored, and shipped at $4{ }^{\circ} \mathrm{C}$ within 8 hours for subsequent experiments.

\section{Isolation of cPBMCs}


165 Cetacean peripheral blood leukocytes (cPBLs) were collected by slow spin method with

166 minor modifications (Bossart et al. 2008). The isolated cPBLs were resuspended in RPMI-1640

167 (Gibco, NY, USA) with 10\% ethylenediaminetetraacetic acid (EDTA) and subsequently used in

168 the isolation of cPBMCs by density gradient centrifugation method. After centrifugation at 1200

$169 \times \mathrm{g}$ for $30 \mathrm{~min}$ at $20^{\circ} \mathrm{C}$, the cPBMCs were collected from the cell layer between the RPMI-1640

170 (Gibco) and Ficoll-Paque PLUS (GE Healthcare, Uppsala, Sweden), washed with RPMI-1640

171 twice, resuspended to a final concentration of $1 \times 10^{7}$ cells $/ \mathrm{ml}$ in complete RPMI-1640 media,

172 and kept on ice until they were utilized in subsequent experiments. The cell viability of cPBMCs

173 was determined by the trypan blue exclusion method using a hemacytometer, and the cell purity

174 based on the cell size (forward-scattered light; FSC) and inner complexity (side-scattered light;

175 SSC) of cPBMCs were determined by FACScalibur flow cytometry (BD, CA, USA). The

176 cPBMCs with higher than $90 \%$ viability and $80 \%$ purity were used in this study.

177 Determination of the sub-lethal dose of $\mathrm{C}-\mathrm{AgNP}_{20}$ on $\mathbf{c P B M C s}$ with/without concanavalin $\mathrm{A}$

178 (ConA)

179 The cytotoxicity of $\mathrm{C}-\mathrm{AgNP}_{20}$ on cPBMCs was evaluated by the Annexin V-FITC/PI

180 Apoptosis Detection Kit (Strong Biotech, Taipei, Taiwan) according to the manufacturer's

181 instructions. Freshly-isolated cPBMCs were seeded in 96-well plates at a density of $5 \times 10^{5}$

182 cells/well and exposed to $\mathrm{C}-\mathrm{AgNP}_{20}$ at concentrations of $0,0.1,1.0$ and $10 \mu \mathrm{g} / \mathrm{ml}$ with or without 
$1832 \mu \mathrm{g} / \mathrm{ml}$ ConA (Sigma-Alderich, MO, USA). After $24 \mathrm{~h}$ of culture, cells were collected and

184 resuspended in binding buffer for further analysis by FACScalibur flow cytometry (BD). The

185 percentages of early apoptotic $(\mathrm{PI}-$ and Annexin +$)$ and late apoptotic/necrotic cells $(\mathrm{PI}+$ and

186 Annexin + ) were determined. A total of 8,000 events/sample were acquired. The sub-lethal doses

187 of $\mathrm{C}-\mathrm{AgNP}_{20}$ for cPBMCs were determined and subsequently used in the cytokine expression

188 assay.

189 qRT-PCR efficiency of each primer sets

190 The primer sets used in cytokine expression assay are summarized in Table 2. The

191 amplification efficiency (E) of qRT-PCR with each primer set was evaluated by the slope and $\mathrm{R}^{2}$

192 of standard curves using the equation: $E=10^{-(1 / \text { slope })}-1$ (Svec et al. 2015). The standard

193 templates for qRT-PCR with target primer sets were prepared by serial dilution of PCR products,

194 which were amplified from cDNA samples of isolated cPBMCs with target primer sets. The PCR

195 product was 500-fold diluted with subsequent six steps of serial 10-fold dilutions, and

196 subsequently used for qRT-PCR. The Cycle threshold $(\mathrm{Ct})$ values of each dilution were

197 evaluated by qRT-PCR with each primer set to generate the standard curves.

198 Extraction of RNA, synthesis of cDNA and qRT-PCR

199 Total RNA was extracted from blood samples by RNeasy ${ }^{\circledR}$ Mini Kit (Qiagen, Valencia, CA,

200 USA) according to the manufacturer's instructions. The RNA samples were treated with 
201 genomic DNA (gDNA) wipeout solution (Qiagen). Treated samples were then tested by qRT-

202 PCR to confirm the absence of residue gDNA prior to cDNA synthesis. The QuantiTect ${ }^{\circledR}$

203 Reverse Transcription kit (Qiagen) was used for cDNA synthesis. The reverse transcription was

204 conducted within 4 hours after RNA extraction. The cDNA from each sample was stored at -20

$205{ }^{\circ} \mathrm{C}$ for qRT-PCR. The qRT-PCR was performed on Mastercycler ${ }^{\circledR}$ ep realplex (Eppendorf,

206 Hamburg, Germany). Each reaction contained $10 \mu 1$ of SYBR ${ }^{\circledR}$ Advantage ${ }^{\circledR}$ qPCR Premix

207 (Clontech, California, USA), $7.2 \mu \mathrm{l}$ of RNase/DNase-free sterile water, $0.4 \mu \mathrm{l}$ of each $10 \mathrm{mM}$

208 forward/reverse primers, and $2 \mu \mathrm{l}$ of DNA template, and the final volume of each reaction was 20

$209 \mu \mathrm{l}$. Two microliters of RNase/DNase-free sterile water was used as the non-template negative

210 control. The thermocycle conditions were set as follows: initial denaturation at $95^{\circ} \mathrm{C}$ for $30 \mathrm{~s}$

211 and 40 cycles of denaturation at $95{ }^{\circ} \mathrm{C}$ for $10 \mathrm{~s}$, annealing at $60^{\circ} \mathrm{C}$ for $20 \mathrm{~s}$, and extension at 72

$212{ }^{\circ} \mathrm{C}$ for $30 \mathrm{~s}$ with fluorescence detection. Furthermore, the melting curve analysis was performed

213 at the end to identify non-specific amplification. All PCR protocols were performed in

214 accordance with the Minimum Information for Publication of Quantitative Real-Time PCR

215 Experiments (MIQE) guidelines (Bustin et al. 2009; Taylor \& Mrkusich 2014).

216 Time kinetics of mRNA expression levels of selected cytokines of cPBMCs

217 To evaluate the time kinetics of mRNA expression levels of selected cytokines in cPBMCs

218 with ConA, the cytokine gene expression levels of cPBMCs with ConA $(0.5 \mu \mathrm{g} / \mathrm{ml})$ were 
219 determined by qRT-PCR (N=4). Freshly-isolated cPBMCs were seeded in 96-well plates at a

220 density of $5 \times 10^{5}$ cells/well and incubated for $0,4,8,12,16,20$ and $24 \mathrm{~h}$ of culture in a

221 humidified atmosphere of $5 \% \mathrm{CO}_{2}$ at $37^{\circ} \mathrm{C}$. Then the cPBMCs were collected for subsequent

222 mRNA extraction, complementary DNA (cDNA) synthesis, and qRT-PCR. The cPBMCs with 0

$223 \mathrm{~h}$ incubation were used as control for the calculation of cytokine expression level by $\Delta \Delta \mathrm{CT}$

224 method. In addition, the geometric means of two housekeeping genes (HKGs), glyceraldehyde 3-

225 phosphate dehydrogenase (GAPDH) and $\beta 2$-microglobulin (B2M), of each sample were

226 determined and used to normalize the expression levels of target genes (Hellemans et al. 2007;

227 Vandesompele et al. 2002).

228 Effects of C-AgNP ${ }_{20}$ on mRNA expression levels of selected cytokines of cPBMCs

229 The cPBMCs were seeded in 96-well plates at a density of $5 \times 10^{5}$ cells/well and exposed to

230 sub-lethal doses of C-AgNP 20 with $0.5 \mu \mathrm{g} / \mathrm{ml}$ ConA for 4 and $24 \mathrm{~h}$ of culture in a humidified

231 atmosphere of $5 \% \mathrm{CO}_{2}$ at $37{ }^{\circ} \mathrm{C}$. After incubation, the cPBMCs were collected for subsequent

232 mRNA extraction, cDNA synthesis, and qRT-PCR. PBMCs with 4 and $24 \mathrm{~h}$ incubation without

$233 \mathrm{C}-\mathrm{AgNP}_{20}$ treatment were used as control for the calculation of cytokine expression level by

$234 \Delta \Delta \mathrm{CT}$ method. In addition, the geometric means of two HKGs, GAPDH and B2M, of each

235 sample were determined and used to normalize the expression levels of target genes (Hellemans 
236 et al. 2007; Vandesompele et al. 2002). The experiment was independently repeated twice in

237 duplicate $(\mathrm{N}=12)$.

238 Statistical analysis

239 In all experiments, the results from duplicates were averaged. To compensate for individual

240 differences, the results at different concentrations of $\mathrm{C}-\mathrm{AgNP}_{20}$ for each individual were

241 calculated as percentages of the results of the control (exposed to $0 \mu \mathrm{g} / \mathrm{ml} \mathrm{C}-\mathrm{AgNP}_{20}$ ). In

242 addition, $\mathrm{Th} 1 / \mathrm{Th} 2$ ratios at different concentrations of $\mathrm{C}-\mathrm{AgNP}_{20}$ were determined by the

243 cytokine mRNA ratios of Th1 (IL-12 or INF- $\gamma$ ) and Th2 (IL-4) polarizing cytokines and then

244 compared to the control. Our data were first checked by Shapiro-Wilk normality test and Brown-

245 Forsythe test, and the results indicated that the assumptions of normality and/or equal variance

246 were violated. Therefore, the Kruskal-Wallis Test (post hoc test: Dunn's multiple comparison

247 test) was subsequently performed on the data. A $p$ value $<0.05$ was considered statistically

248 significant, and the analysis was performed in Prism (GraphPad Software, CA, USA). All data

249 were plotted on box-plot graphics. The bar in the middle of the box represented the second

250 quartile (median), and the bottom and top of the box described the first and third quartiles. The

251 whiskers showed that the 75th percentile plus 1.5 times IQR and 25th percentile minus 1.5 times

252 IQR of all data, and any values that greater than these were defined as outliers and plotted as 
253 individual points. Asterisks above the boxplots indicated statistically significant differences

254 compared to the control of each experiment.

\section{Results}

\section{Characterization of $\mathbf{C}-\mathbf{A g N P}_{\mathbf{2 0}}$}

257 The C-AgNP 20 in complete RPMI-1640 media were spherical and close to $20 \mathrm{~nm}$ in diameter

258 (Fig. 1). The size distributions and zeta potentials of C-AgNP $20(100$ or $500 \mu \mathrm{g} / \mathrm{ml})$ in $2 \mathrm{mM}$

259 citrate buffer are illustrated in Table 1. The size distributions were $30.27 \pm 0.18(100 \%)$ and

$26029.64 \pm 0.30(100 \%)$ for $\mathrm{C}-\mathrm{AgNP}_{20}$ at 100 and $500 \mu \mathrm{g} / \mathrm{ml}$, respectively. The values of the zeta

261 potential were $-38.97 \pm 1.33$ and $-44.2 \pm 1.35 \mathrm{mV}$ for $\mathrm{C}-\mathrm{AgNP}_{20}$ at 100 and $500 \mu \mathrm{g} / \mathrm{ml}$,

262 respectively. Furthermore, the Poly-dispersity Indexes (PDIs) were $0.12 \pm 0.00$ and $0.11 \pm 0.01$,

263 indicating that the composition of $\mathrm{C}-\mathrm{AgNP}_{20}$ in the stock was in a single size mode without

264 aggregates.

265 Sub-lethal dose of $\mathbf{C}-\mathbf{A g N P}_{20}$ to the cPBMCs with or without ConA stimulation

266 The treatment of $\mathrm{C}-\mathrm{AgNP}_{20}$ at $10 \mu \mathrm{g} / \mathrm{ml}$ significantly increased the ratios of late

267 apoptotic/necrotic cells in cPBMCs with or without ConA stimulation. The ratios of early

268 apoptotic and late apoptotic/necrotic cells of cPBMCs with different concentrations of $\mathrm{C}-\mathrm{AgNP}_{20}$

269 as compared to the control are presented in Fig. 2. After $24 \mathrm{~h}$ of $10 \mu \mathrm{g} / \mathrm{ml} \mathrm{C-AgNP}{ }_{20}$ treatment,

270 the ratios of late apoptotic/necrotic cells of cPBMCs significantly increased with (median \pm 
271 interquartile range (IQR): $3.55 \pm 3.42 ; p=0.0073$ ) or without ConA stimulation (median $\pm \mathrm{IQR}$ :

$2721.78 \pm 2.24 ; p=0.0103)$. In contrast, no statistically significant increases in the ratios of apoptotic

273 and late apoptotic/necrotic cells in cPBMCs were found after $24 \mathrm{~h}$ culture with 0.1 and $1.0 \mu \mathrm{g} / \mathrm{ml}$

$274 \mathrm{C}-\mathrm{AgNP}_{20}$ treatments. Therefore, 0.1 and $1.0 \mu \mathrm{g} / \mathrm{ml} \mathrm{C-AgNP}{ }_{20}$ were defined as the sub-lethal

275 doses for cPBMCs and used in the subsequent mRNA expression levels of selected cytokines in

276 cPBMCs to C-AgNP 20 .

277 qRT-PCR efficiency of each primer set

278 Amplification efficiency (E) values for selected HKGs and cytokine genes, including GAPDH,

279 B2M, IL-2, IL-4, IL-10, and IL-12, IFN- $\gamma$, and TNF- $\alpha$, ranged from 91.08 to $101.48 \%$ with $\mathrm{R}^{2}>$

280 0.99. The results are summarized in Table 2.

281 Time kinetics of mRNA expression levels of selected cytokines of cPBMCs with ConA

282 stimulation

283 The mRNA expression levels of IL-2 and TNF- $\alpha$ were significantly increased at $4 \mathrm{~h}$ of culture,

284 gradually decreased from 8 to $20 \mathrm{~h}$ of culture, and then mildly but not significantly increased at

$28524 \mathrm{~h}$ of culture. The mRNA expression level of IFN- $\gamma$ was significantly increased at $4 \mathrm{~h}$ of

286 culture, gradually decreased at 8 and $12 \mathrm{~h}$ of culture, and then increased from 16 to $24 \mathrm{~h}$ of

287 culture. In addition, IL-4, IL-10, and IL-12 were significantly increased at $4 \mathrm{~h}$ of culture and 
288 gradually decreased over time. Therefore, the time points chosen for the following experiments

289 were $4 \mathrm{~h}$ and $24 \mathrm{~h}$. All the results are illustrated in Fig. 3.

290 Effects of $\mathbf{C}-\mathrm{AgNP}_{\mathbf{2 0}}$ on mRNA expression levels of selected cytokines in cPBMCs

291 At $4 \mathrm{~h}$ of culture, the mRNA expression level of IL-10 was significantly decreased (median \pm

292 IQR: $0.7864 \pm 0.2355 ; p=0.0049)$ at $1 \mu \mathrm{g} / \mathrm{ml} \mathrm{C}-\mathrm{AgNP}_{20}$, but no significant differences were

293 observed in the mRNA expression levels of other cytokine genes at 0.1 or $1 \mu \mathrm{g} / \mathrm{ml} \mathrm{C-AgNP} 20$

294 (Figs. 4). Following $24 \mathrm{~h}$ of culture with $1 \mu \mathrm{g} / \mathrm{ml} \mathrm{C-AgNP} 20$, the mRNA expression levels of IL-

295 2, IL-12, IFN- $\gamma$, and TNF- $\alpha$ were significantly decreased, but no significant difference was found

296 in those of IL-4 and IL-10. Furthermore, the mRNA expression levels of IL-12 (median \pm IQR:

$2970.8337 \pm 0.2088 ; p=0.0339)$ and IFN $-\gamma($ median \pm IQR: $0.7894 \pm 0.389 ; p=0.0164)$ were also

298 significantly decreased at $0.1 \mu \mathrm{g} / \mathrm{ml} \mathrm{C-AgNP}{ }_{20}$ (Figs. 4). The Th1/Th2 bias was defined by the

299 ratios of Th1 and Th2 polarizing cytokines. The IFN- $\gamma /$ IL-4 ratio was significantly decreased

300 following $24 \mathrm{~h}$ of culture with $1 \mu \mathrm{g} / \mathrm{ml} \mathrm{C}-\mathrm{AgNP}_{20}$, and the IL-12/IL-4 ratio was significantly

301 decreased following 4 or $24 \mathrm{~h}$ of culture with 0.1 or $1 \mu \mathrm{g} / \mathrm{ml} \mathrm{C-AgNP}{ }_{20}$ treatments. Overall, the

302 in vitro cytokine responses of $\mathrm{cPBMCs}$ with $\mathrm{C}-\mathrm{AgNP}_{20}$ treatments were biased toward $\mathrm{Th} 2$

303 cytokine response (Fig. 5).

\section{Discussion}


305 Our data indicated that the concentration of $10 \mu \mathrm{g} / \mathrm{ml} \mathrm{C-AgNP}{ }_{20}$ was lethal dose for cPBMCs

306 after $24 \mathrm{~h}$ of culture. Although previous studies of human PBMCs have used a variety of AgNPs

307 (including different sizes and coatings), the lethal dose of AgNPs to human PBMCs is generally

308 higher than $10 \mu \mathrm{g} / \mathrm{ml}$ (Ghosh et al. 2012; Greulich et al. 2011; Huang et al. 2016a; Orta-Garcia et

309 al. 2015; Paino \& Zucolotto 2015; Shin et al. 2007). Therefore, our data suggest that cPBMCs

310 may be more vulnerable than human PBMCs to the cytotoxic effects of $\mathrm{C}-\mathrm{AgNP}_{20}$. However,

311 previous studies have demonstrated that the toxicity and physicochemical characteristics of

312 AgNPs are associated with their surface coating and size (Kim \& Ryu 2013), and thus further

313 investigation using the same AgNPs from the same manufacturer is necessary to compare the

314 differences of susceptibility between cetaceans and humans. In addition, the negative effects of

315 AgNPs with different sizes and coatings on the cPBMCs are also worth to be further studied.

316 It has been demonstrated that ConA (a selective T-cell mitogen) induces proliferative

317 activity and gene expression of cytokines in bottlenose dolphins, but no information is available

318 regarding the time course (Hofstetter et al. 2017; Segawa et al. 2013; Sitt et al. 2008). Previous

319 studies on ConA-induced cytokine mRNA expression levels of cPBMCs only presented one or

320 two time points (Segawa et al. 2013; Sitt et al. 2008). Sitt et al. (2008) quantified the ConA-

321 induced cytokine mRNA expression levels of cPBMCs after $48 \mathrm{~h}$ of treatment, but the reason for

322 choosing this time point was not explained. Their results showed that the mRNA expression 
323 levels of IL-2, IL-4, IL-12, and IFN- $\gamma$ in cPBMCs are induced after $48 \mathrm{~h}$ of ConA stimulation,

324 but those of IL-10 and TNF- $\alpha$ were not increased (Sitt et al. 2008). The other study demonstrated

325 that the mRNA expression level of IL-10 in cPBMCs increased after $6 \mathrm{~h}$ of ConA stimulation

326 (Segawa et al. 2013). Therefore, to apply appropriate time points for studying the effects of C-

$327 \mathrm{AgNP}_{20}$ on the cytokine mRNA expression levels of cPBMCs, the time kinetics (from 0 to $24 \mathrm{~h}$ )

328 of mRNA expression levels of IL-2, IL-4, IL-10, IL-12, IFN- $\gamma$ and TNF- $\alpha$ in cPBMCs with

329 ConA stimulation were investigated. Our data indicated that the mRNA expression levels of all

330 cytokine genes were significantly increased at $4 \mathrm{~h}$ of ConA stimulation and then gradually

331 decreased with time. A longer incubation time was not possible in our study because the cell

332 numbers of isolated cPBMCs were insufficient.

333 Previous studies have investigated the negative effects of AgNPs on cytokines in human

334 PBMCs (Franco-Molina et al. 2016; Greulich et al. 2011; Shin et al. 2007). Uncoated AgNPs

$335(1.5 \mathrm{~nm} ; 1$ to $2.5 \mathrm{~nm}$ in diameter) significantly inhibited the phytohemagglutinin (PHA)-induced

336 IL-5, IFN- $\gamma$, and TNF- $\alpha$ production respectively at concentrations $\geq 10 \mu \mathrm{g} / \mathrm{ml}, \geq 3 \mu \mathrm{g} / \mathrm{ml}$, and $\geq 3$

$337 \mu \mathrm{g} / \mathrm{ml}$ in human PBMCs (Shin et al. 2007). It was reported that uncoated AgNPs (100 nm; 90 to

$338190 \mathrm{~nm}$ in diameter) at $0.0175 \mu \mathrm{g} / \mathrm{ml}$ can inhibit both PHA and ConA-induced IL-2 production in

339 human PBMCs (Franco-Molina et al. 2016). Furthermore, polyvinylpyrrolidone (PVP)-coated

340 AgNPs $(75 \pm 20 \mathrm{~nm})$ of 5 to $20 \mu \mathrm{g} / \mathrm{ml}$ significantly increased the generations of IL- 6 and IL-8 
341 but significantly decreased the release of IL-1 ra from human PBMCs, while PVP-coated AgNPs

342 did not affect the productions of IL-2, IL-4 and TNF-a (Greulich et al. 2011). As mentioned

343 above, the effects of AgNPs on cytokine production in human PBMCs remain inconclusive.

344 The mRNA expression levels of IL-4 and IFN- $\gamma$ were mildly increased and that of IL-12

345 was seemingly unaffected at $4 \mathrm{~h}$ of $\mathrm{C}-\mathrm{AgNP}_{20}$ treatment. IL-4, as a polarizing Th2 cytokine, is

346 mainly produced by T cells (especially the Th2 subset) and mast cells, and it promotes the

347 differentiation of naïve $\mathrm{T}$ cells to Th2 cells, stimulates the growth and differentiation of $\mathrm{B}$ cells,

348 and induces class switching to IgE, which may promote allergic responses (Owen et al. 2013;

349 Tizard 2013b). IFN- $\gamma$, as a polarizing Th1 cytokine and a key mediator of cell-mediated immune

350 response, is produced by Th1 cells, cytotoxic T cells, and NK cells. The major functions of IFN-

$351 \gamma$ are enhancement of Th1 differentiation, inhibition of Th2 differentiation, and activations of NK

352 cells and macrophages (Owen et al. 2013; Tizard 2013b). IL-12 is also a polarizing Th1 cytokine

353 and is produced by dendritic cells, monocytes, macrophages and B cells. IL-12 induces

354 differentiation of Th1 cells, increases IFN- $\gamma$ production by T cells and NK cells, and enhances

355 NK and cytotoxic T cell activity (Owen et al. 2013; Tizard 2013b). This mixed pattern of Th1

356 and Th2 cytokines may be indicative of a mixed Th1/Th2 cytokine response of cPBMCs at $4 \mathrm{~h}$ of

$357 \mathrm{C}-\mathrm{AgNP}_{20}$ treatment. However, considering the significant decrease in the IL-12/IL-4 ratio, Th2

358 cytokine response is still predominant in cPBMCs following $4 \mathrm{~h}$ of $\mathrm{C}-\mathrm{AgNP}_{20}$ treatment. The 
359 mRNA expression levels of IL-12 and IFN- $\gamma$ were significantly decreased by $0.1 \mathrm{or} 1 \mu \mathrm{g} / \mathrm{ml} \mathrm{C}$ -

$360 \mathrm{AgNP}_{20}$, and that of IL-4 was seemingly unaffected, in cPBMCs following $24 \mathrm{~h}$ of culture. The

361 significantly decreased Th1/Th2 (i.e., IFN- $/$ /IL-4 and IL-12/IL-4) ratios suggested that the

362 immune response of cPBMCs following $24 \mathrm{~h}$ of $\mathrm{C}-\mathrm{AgNP}_{20}$ treatment is $\mathrm{Th} 2$ biased.

363 Furthermore, the mRNA expression level of TNF- $\alpha$ was significantly decreased by $1 \mu \mathrm{g} / \mathrm{ml}$

$364 \mathrm{C}-\mathrm{AgNP}_{20}$ after $24 \mathrm{~h}$ of culture. TNF-a is a cytokine specifically useful to measure the

365 inflammatory state of an animal and it is primarily produced by macrophages and both Th1 and

366 Th2 cells in response to both acute and chronic conditions (Eberle et al. 2018). Previous studies

367 have demonstrated that TNF- $\alpha$ is a contributing factor in the inflammatory response against

368 infection of intracellular micropathogens such as Plasmodium spp., T. gondii, Leishmania major,

369 and Trypanosoma spp. (Korner et al. 2010). Hence, our data indicate that C-AgNP ${ }_{20}$ induced a

370 Th2 biased immune response and suppressed the mRNA expression level of TNF- $\alpha$ in cPBMCs,

371 which may weaken the cellular immune response and further impair the immunity against

372 intracellular organisms and virus. Similar Th2 immune response was observed in other studies

373 that evaluated the expression of cytokines in different cetacean tissues (Jaber et al. 2010). A

374 variety of infections caused by intracellular pathogens in cetaceans have been reported and may

375 be associated with the mass stranding events of cetaceans (Cvetnic et al. 2016; Domingo et al.

376 1990; Domingo et al. 1992; Dubey et al. 2007; Dubey et al. 2008; Mazzariol et al. 2016; 
377 Mazzariol et al. 2017). In addition, previous studies suggested that Ag contamination exists in all

378 aspects of the marine ecosystem, and cetaceans may have been negatively affected by $\mathrm{Ag}$

379 contamination (Becker et al. 1995; Caceres-Saez et al. 2013; Chen et al. 2017; Dehn et al. 2006;

380 Kunito et al. 2004; Li et al. 2018a; Mendez-Fernandez et al. 2014; Reed et al. 2015; Rosa et al.

381 2008; Seixas et al. 2009; Woshner et al. 2001). The direct correlation between the infection of

382 intracellular pathogens and the severity of Ag contamination in cetaceans is worth studying.

383 Following $4 \mathrm{~h}$ of $1 \mu \mathrm{g} / \mathrm{ml} \mathrm{C}-\mathrm{AgNP}_{20}$ treatment, the mRNA expression level of IL-10 was

384 significantly decreased and that of IL-2 was mildly increased. In other words, mRNA expression

385 levels of IL-2 and IL-10 were respectively upregulated and downregulated by C-AgNP 20 in

386 cPBMCs. Subsequently, the mRNA expression level of IL-2 was significantly decreased, and

387 that of IL-10 seemingly unaffected, in cPBMCs following $24 \mathrm{~h}$ of treatment of $1 \mu \mathrm{g} / \mathrm{ml} \mathrm{C}$ -

$388 \mathrm{AgNP}_{20}$. IL-2, which is produced by activated $\mathrm{T}$ cells, can stimulate proliferation and

389 differentiation of T and B cells and activates NK cells (Owen et al. 2013; Tizard 2013b).

390 However, a growing body of evidence has indicated that IL-2 is crucial for the development and

391 function of regulatory T cells (Treg cells), which secrete effector cytokines, such as IL-10, to

392 control and modulate the immunity to self, neoplasia, microorganisms, and grafts (Owen et al.

393 2013; Pérol \& Piaggio 2016). Considering the roles of IL-2 and IL-10 in immune tolerance, it is 
394 speculated that $\mathrm{C}-\mathrm{AgNP}_{20}$ may play a significant role in peripheral immune tolerance by

395 regulating the balance between IL-2 and IL-10 (Pérol \& Piaggio 2016; Veiopoulou et al. 2004).

396 The effect of $\mathrm{C}-\mathrm{AgNP}_{20}$ on the ConA-induced mRNA expression levels of the selected

397 cytokines in cPBMCs is mainly inhibitory. A previous study found that PVP-AgNPs (10, 25, 40,

39845 , and $110 \mathrm{~nm}$ in diameter) could bind to RNA polymerase, disturb the process of RNA

399 transcription, and thus decreased the overall RNA synthesis in mouse erythroid progenitor cells

400 (Wang et al. 2013). Although the down-regulation of mRNA expression levels may be associated

401 with decreased RNA synthesis due to the direct interaction between $\mathrm{C}-\mathrm{AgNP}_{20}$ and RNA

402 polymerase, it cannot fully explain the unaffected Th2 cytokines (IL-4 and IL-10) of cPBMCs in

403 this study. On the other hand, the ConA-induced proliferative activity of cPBMCs is inhibited by

4040.1 and $1.0 \mu \mathrm{g} / \mathrm{ml} \mathrm{C-AgNP}{ }_{20}$ (Li et al. 2018b), and this phenomenon may be associated with the

405 decreased mRNA expression levels of IL-2, IL-12, IFN- $\gamma$, and TNF- $a$ and/or a suppressive effect

406 on DNA/RNA synthesis induced by ConA. Further investigation on the underlying mechanism

407 of AgNPs in cetacean leukocytes is important to ascertain the negative health impact caused by

408 AgNPs on cetaceans, and such investigation would improve the understanding of the potential

409 hazards of AgNPs to environmental condition and human health.

410 Furthermore, although the biodistribution of AgNPs or Ag in cetaceans is still

411 undetermined, previous in vivo studies of AgNPs by oral exposure in laboratory rats 
412 demonstrated that the $\mathrm{Ag}$ concentration in the liver is approximately 10 times higher than that in

413 the blood or plasma (Lee et al. 2013; Loeschner et al. 2011; van der Zande et al. 2012). Based on

414 these animal models, it is presumed that the Ag concentrations in the blood of cetaceans may

415 range from 0.01 to $72.6 \mu \mathrm{g} / \mathrm{ml}$ (Chen et al. 2017; Li et al. 2018a). Although previous studies have

416 indicated that the status of AgNPs in the aquatic environment is complicated and variable (i.e.,

417 the concentrations of AgNPs and other $\mathrm{Ag} / \mathrm{Ag}$ compounds are still undetermined in

418 cetaceans)(Levard et al. 2012; Massarsky et al. 2014), our data suggest that cetaceans may be

419 negatively affected by AgNPs.

\section{Conclusions}

421 The present study has demonstrated 1) the sublethal dose of C-AgNP 20 to cPBMCs $(\leq 1$

$422 \mu \mathrm{g} / \mathrm{ml}), 2$ ) the time kinetics of mRNA expression levels of selected cytokines in cPBMCs, and 3)

423 the inhibitory effect of $\mathrm{C}-\mathrm{AgNP}_{20}(0.1$ and $1 \mu \mathrm{g} / \mathrm{ml})$ on the mRNA expression levels of selected

424 cytokines of cPBMCs with evidence of Th2 cytokine bias. Taken together, $\mathrm{C}-\mathrm{AgNP}_{20}$ may

425 suppress the cellular immune response and thus inhibit the immunity against intracellular

426 microorganisms in cetaceans.

\section{Acknowledgements}


428 We thank all the personnel of Farglory Ocean Park for blood sample collection and storage,

429 the dolphins in Farglory Ocean Park for donating their blood, and Dr. Bang-Yeh Liou for blood

430 sample transportation. 


\section{References}

432 Becker P, Mackey E, Demiralp R, Suydam R, Early G, Koster B, Wise S. 1995. Relationship of silver with selenium and mercury in the liver of two species of toothed whales 326X(94)00176-A.

Beineke A, Siebert U, van Elk N, Baumgartner W. 2004. Development of a lymphocytetransformation-assay for peripheral blood lymphocytes of the harbor porpoise and 10.1016/j.vetimm.2003.10.002.

Beineke A, Siebert U, Wohlsein P, Baumgartner W. 2010. Immunology of whales and dolphins. Veterinary Immunology and Immunopathology 133:81-94. DOI: 10.1016/j.vetimm.2009.06.019.

444 Bossart GD, Romano TA, Peden-Adams MM, Rice CD, Fair PA, Goldstein JD, Kilpatrick D, Atlantic bottlenose dolphins (Tursiops truncatus) with orogenital papillomas. Aquat 
448 Buffet PE, Zalouk-Vergnoux A, Chatel A, Berthet B, Metais I, Perrein-Ettajani H, Poirier L,

449 Luna-Acosta A, Thomas-Guyon H, Risso-de Faverney C, Guibbolini M, Gilliland D,

450 Valsami-Jones E, Mouneyrac C. 2014. A marine mesocosm study on the environmental

451 fate of silver nanoparticles and toxicity effects on two endobenthic species: the ragworm

452 Hediste diversicolor and the bivalve mollusc Scrobicularia plana. Science of the Total

453 Environment 470-471:1151-1159. DOI: 10.1016/j.scitotenv.2013.10.114.

454 Bustin SA, Benes V, Garson JA, Hellemans J, Huggett J, Kubista M, Mueller R, Nolan T, Pfaffl

Chemistry 55:611-622. DOI: 10.1373/clinchem.2008.112797. metals and essential elements in Commerson's dolphins (Cephalorhynchus $c$. and Assessment 185:5375-5386. DOI: 10.1007/s10661-012-2952-y.

462 Chen IH, Chou LS, Chou SJ, Wang JH, Stott J, Blanchard M, Jen IF, Yang WC. 2015. Selection of suitable reference genes for normalization of quantitative RT-PCR in peripheral blood samples of bottlenose dolphins (Tursiops truncatus). Scientific Reports 5:15425. DOI: $10.1038 /$ srep 15425 . 
466 Chen MH, Zhuang MF, Chou LS, Liu JY, Shih CC, Chen CY. 2017. Tissue concentrations of

467 four Taiwanese toothed cetaceans indicating the silver and cadmium pollution in the

468 western Pacific Ocean. Marine Pollution Bulletin 124:993-1000. DOI:

469 10.1016/j.marpolbul.2017.03.028.

Cvetnic Z, Duvnjak S, Duras M, Gomercic T, Reil I, Zdelar-Tuk M, Spicic S. 2016. Evidence of Brucella strain ST27 in bottlenose dolphin (Tursiops truncatus) in Europe. Veterinary Microbiology 196:93-97. DOI: 10.1016/j.vetmic.2016.10.013.

Dehn LA, Follmann EH, Thomas DL, Sheffield GG, Rosa C, Duffy LK, O'Hara TM. 2006. Trophic relationships in an Arctic food web and implications for trace metal transfer. Science of the Total Environment 362:103-123. DOI: 10.1016/j.scitotenv.2005.11.012.

Desforges JP, Sonne C, Levin M, Siebert U, De Guise S, and Dietz R. 2016. Immunotoxic effects of environmental pollutants in marine mammals. Environment International 1990. Morbillivirus in dolphins. Nature 348:21. DOI: 10.1038/348021a0. and immunocytochemical studies of morbillivirus infection in striped dolphins (Stenella coeruleoalba). Veterinary Pathology 29:1-10. DOI: 10.1177/030098589202900101 
484 Dubey JP, Fair PA, Sundar N, Velmurugan G, Kwok OC, McFee WE, Majumdar D, Su C. 2008.

485

486

487

488

489

490

491

492

493

494

495

496

497

498

499

500

501
Isolation of Toxoplasma gondii from bottlenose dolphins (Tursiops truncatus). Journal of

Parasitology 94:821-823. DOI: 10.1645/GE-1444.1.

Dubey JP, Morales JA, Sundar N, Velmurugan GV, Gonzalez-Barrientos CR, Hernandez-Mora

G, Su C. 2007. Isolation and genetic characterization of Toxoplasma gondii from striped

dolphin (Stenella coeruleoalba) from Costa Rica. Journal of Parasitology 93:710-711.

DOI: 10.1645/GE-1120R.1.

Eberle KC, Venn-Watson SK, Jensen ED, LaBresh J, Sullivan Y, Kakach L, Sacco RE. 2018.

Development and testing of species-specific ELISA assays to measure IFN-gamma and

TNF-alpha in bottlenose dolphins (Tursiops truncatus). PLoS One 13:e0190786. DOI:

10.1371/journal.pone.0190786

Espinosa-Cristobal LF, Martinez-Castanon GA, Loyola-Rodriguez JP, Patino-Marin N, Reyes-

Macias JF, Vargas-Morales JM, Ruiz F. 2013. Toxicity, distribution, and accumulation of silver nanoparticles in Wistar rats. Journal of Nanoparticle Research 15:1702. DOI:

10.1007/S11051-013-1702-6.

Farre M, Gajda-Schrantz K, Kantiani L, Barcelo D. 2009. Ecotoxicity and analysis of nanomaterials in the aquatic environment. Analytical and Bioanalytical Chemistry 393:81-95. DOI: 10.1007/s00216-008-2458-1. 
502 Franco-Molina MA, Mendoza-Gamboa E, Zarate-Triviño DG, Coronado-Cerda EE, Alcocer-

503 González JM, Resendez-Pérez D, Rodríguez-Salazar MC, Rivera-Morales LG, Tamez-

504 Guerra R, Rodríguez-Padilla C. 2016. In Vitro Evaluation of Colloidal Silver on Immune

505 Function: Antilymphoproliferative Activity. Journal of Nanomaterials 2017:1-12. DOI:

506 $10.1155 / 2016 / 4176212$

507 Gambardella C, Costa E, Piazza V, Fabbrocini A, Magi E, Faimali M, Garaventa F. 2015. Effect

508 of silver nanoparticles on marine organisms belonging to different trophic levels. Marine

509 Environmental Research 111:41-49. DOI: 10.1016/j.marenvres.2015.06.001.

510 Gagne F, Auclair J, Fortier M, Bruneau A, Fournier M, Turcotte P, Pilote M, Gagnon C. 2013.

511 Bioavailability and immunotoxicity of silver nanoparticles to the freshwater mussel

512 Elliptio complanata. Journal of Toxicology and Environmental Health, Part A 76:767-

513 777. DOI: $10.1080 / 15287394.2013 .818602$.

514 Ghosh M, J M, Sinha S, Chakraborty A, Mallick SK, Bandyopadhyay M, Mukherjee A. 2012. In

515 vitro and in vivo genotoxicity of silver nanoparticles. Mutation Research 749:60-69.

516 DOI: 10.1016/j.mrgentox.2012.08.007.

517 Greulich C, Diendorf J, Gessmann J, Simon T, Habijan T, Eggeler G, Schildhauer TA, Epple M, Koller M. 2011. Cell type-specific responses of peripheral blood mononuclear cells to 
521 Hellemans J, Mortier G, De Paepe A, Speleman F, Vandesompele J. 2007. qBase relative quantification framework and software for management and automated analysis of realtime quantitative PCR data. Genome Biology 8:R19. DOI: 10.1186/gb-2007-8-2-r19.

524 Hofstetter AR, Eberle KC, Venn-Watson SK, Jensen ED, Porter TJ, Waters TE, Sacco RE. 2017.

525 Monitoring bottlenose dolphin leukocyte cytokine mRNA responsiveness by qPCR. PLoS One 12:e0189437. DOI: 10.1371/journal.pone.0189437. compatibility of silver nanoparticles. Scientific Reports 6:25518. DOI: $10.1038 /$ srep25518.

Huang J, Cheng J, Yi J. 2016b. Impact of silver nanoparticles on marine diatom Skeletonema costatum. Journal of Applied Toxicology 36:1343-1354. DOI: 10.1002/jat.3325. with cetacean tissues. Journal of Comparative Pathology 143:45-51. DOI: 
536 Kidd P. 2003. Th1/Th2 balance: the hypothesis, its limitations, and implications for health and disease. Alternative medicine review 8:223-246.

538 Kim S, Ryu DY. 2013. Silver nanoparticle-induced oxidative stress, genotoxicity and apoptosis in cultured cells and animal tissues. Journal of Applied Toxicology 33:78-89. DOI:

540 10.1002/jat.2792.

541 Korner H, McMorran B, Schluter D, Fromm P. 2010. The role of TNF in parasitic diseases: still more questions than answers. International Journal for Parasitology 40:879-888. DOI: 10.1016/j.ijpara.2010.03.011.

544 Kunito T, Nakamura S, Ikemoto T, Anan Y, Kubota R, Tanabe S, Rosas FC, Fillmann G, Readman JW. 2004. Concentration and subcellular distribution of trace elements in liver of small cetaceans incidentally caught along the Brazilian coast. Marine Pollution Bulletin 49:574-587. DOI: 10.1016/j.marpolbul.2004.03.009 D, Ahn K, Lee JE, Yu IJ. 2013. Biopersistence of silver nanoparticles in tissues from 36. 
552 Levard C, Hotze EM, Lowry GV, Brown GE, Jr. 2012. Environmental transformations of silver nanoparticles: impact on stability and toxicity. Environmental Science and Technology 46:6900-6914. DOI: 10.1021/es2037405.

555

556

557

558

559

560

561

562

563

564

565

566

567 autometallography (AMG). Environmental Pollution 235:534-545. DOI: 10.1016/j.envpol.2018.01.010.

Li WT, Chang HW, Yang WC, Lo C, Wang LY, Pang VF, Chen MH, Jeng CR. 2018b. Immunotoxicity of Silver Nanoparticles (AgNPs) on the Leukocytes of Common Bottlenose Dolphins (Tursiops truncatus). Scientific Reports 8:5593. DOI: 10.1038/s41598-018-23737-0.

Liz R, Simard JC, Leonardi LB, Girard D. 2015. Silver nanoparticles rapidly induce atypical human neutrophil cell death by a process involving inflammatory caspases and reactive oxygen species and induce neutrophil extracellular traps release upon cell adhesion. International Immunopharmacology 28:616-625. DOI: 10.1016/j.intimp.2015.06.030.

Loeschner K, Hadrup N, Qvortrup K, Larsen A, Gao X, Vogel U, Mortensen A, Lam HR, Larsen EH. 2011. Distribution of silver in rats following 28 days of repeated oral exposure to 
571

Massarsky A, Trudeau VL, Moon TW. 2014. Predicting the environmental impact of nanosilver. Environmental Toxicology and Pharmacology 38:861-873. DOI: 10.1016/j.etap.2014.10.006.

Mazzariol S, Centelleghe C, Beffagna G, Povinelli M, Terracciano G, Cocumelli C, Pintore A, Denurra D, Casalone C, Pautasso A, Di Francesco CE, Di Guardo G. 2016. Mediterranean fin whales (Balaenoptera physalus) threatened by dolphin morbillivirus. Emerging Infectious Diseases 22:302-305. DOI: 10.3201/eid2202.15-0882.

Mazzariol S, Centelleghe C, Di Provvido A, Di Renzo L, Cardeti G, Cersini A, Fichi G, Petrella A, Di Francesco CE, Mignone W, Casalone C, Di Guardo G. 2017. Dolphin morbillivirus associated with a mass stranding of sperm whales, Italy. Emerging Infectious Diseases 23:144-146. DOI: 10.3201/eid2301.160239.

Mendez-Fernandez P, Webster L, Chouvelon T, Bustamante P, Ferreira M, Gonzalez AF, Lopez A, Moffat CF, Pierce GJ, Read FL, Russell M, Santos MB, Spitz J, Vingada JV, Caurant F. 2014. An assessment of contaminant concentrations in toothed whale species of the NW Iberian Peninsula: part II. Trace element concentrations. Science of the Total Environment 484:206-217. DOI: 10.1016/j.scitotenv.2014.03.001. 
587 Orta-Garcia ST, Plascencia-Villa G, Ochoa-Martinez AC, Ruiz-Vera T, Perez-Vazquez FJ,

Velazquez-Salazar JJ, Yacaman MJ, Navarro-Contreras HR, Perez-Maldonado IN. 2015.

Analysis of cytotoxic effects of silver nanoclusters on human peripheral blood mononuclear cells 'in vitro'. Journal of Applied Toxicology 35:1189-1199. DOI:

591 10.1002/jat.3190.

Owen JA, Punt J, Stranford SA, Jones PP, Kuby J. 2013. Kuby immunology. New York: W.H.

Pérol L, Piaggio E. 2016. New molecular and cellular mechanisms of tolerance: tolerogenic Freeman. neutrophils and nanotoxicology effects in human hepatocarcinoma and mononuclear actions of IL-2. In: Cuturi MC, Anegon I, eds. Suppression and regulation of immune responses: methods and protocols, volume II. New York: Humana Press, 11-28. $\mathrm{nm}\left(\mathrm{AgNP}_{20}\right)$ and human neutrophils: induction of apoptosis and inhibition of de novo protein synthesis by $\mathrm{AgNP}_{20}$ aggregates. Journal of Applied Toxicology 34:404-412. DOI: $10.1002 /$ jat.2956. 
605 Poirier M, Simard JC, Girard D. 2016. Silver nanoparticles of $70 \mathrm{~nm}$ and $20 \mathrm{~nm}$ affect differently

606 the biology of human neutrophils. Journal of Immunotoxicology 13:375-385. DOI:

607

10.3109/1547691X.2015.1106622.

608 Raphael I, Nalawade S, Eagar TN, Forsthuber TG. 2015. T cell subsets and their signature

609 cytokines in autoimmune and inflammatory diseases. Cytokine 74:5-17. DOI:

$610 \quad$ 10.1016/j.cyto.2014.09.011.

611 Reed LA, McFee WE, Pennington PL, Wirth EF, Fulton MH. 2015. A survey of trace element

612 distribution in tissues of the dwarf sperm whale (Kogia sima) stranded along the South

613 Carolina coast from 1990-2011. Marine Pollution Bulletin 100:501-506. DOI:

$614 \quad$ 10.1016/j.marpolbul.2015.09.005.

615 Rosa C, Blake JE, Bratton GR, Dehn LA, Gray MJ, and O'Hara TM. 2008. Heavy metal and

616 mineral concentrations and their relationship to histopathological findings in the bowhead

617 whale (Balaena mysticetus). Science of the Total Environment 399:165-178. DOI:

$618 \quad$ 10.1016/j.scitotenv.2008.01.062.

619 Sardari RRR, Zarchi SR, Talebi A, Nasri S, Imani S, Khoradmehr A, Sheshde SAR. 2012.

620 Toxicological effects of silver nanoparticles in rats. African Journal of Microbiology

$621 \quad$ Research 6:5587-5593. DOI: 10.5897/Ajmr11.1070. 
622 Segawa T, Karatani N, Itou T, Suzuki M, Sakai T. 2013. Cloning and characterization of

623 bottlenose dolphin (Tursiops truncatus) interleukin-10. Veterinary Immunology and

624 Immunopathology 154:62-67. DOI: 10.1016/j.vetimm.2013.04.009.

625 Seixas TG, Kehrig HA, Di Beneditto AP, Souza CM, Malm O, Moreira I. 2009. Essential (Se,

$626 \mathrm{Cu})$ and non-essential $(\mathrm{Ag}, \mathrm{Hg}, \mathrm{Cd})$ elements: what are their relationships in liver of

627 Sotalia guianensis (Cetacea, Delphinidae)? Marine Pollution Bulletin 58:629-634. DOI:

$628 \quad$ 10.1016/j.marpolbul.2008.12.005.

629 Shahare B, Yashpal M. 2013. Toxic effects of repeated oral exposure of silver nanoparticles on

630

631 small intestine mucosa of mice. Toxicology Mechanisms and Methods 23:161-167. DOI: 10.3109/15376516.2013.764950.

632 Shin SH, Ye MK, Kim HS, Kang HS. 2007. The effects of nano-silver on the proliferation and cytokine expression by peripheral blood mononuclear cells. International Immunopharmacology 7:1813-1818. DOI: 10.1016/j.intimp.2007.08.025.

635 Sitt T, Bowen L, Blanchard MT, Smith BR, Gershwin LJ, Byrne BA, Stott JL. 2008. Quantitation of leukocyte gene expression in cetaceans. Developmental and Comparative Immunology 32:1253-1259. DOI: 10.1016/j.dci.2008.05.001. 
638 Soares T, Ribeiro D, Proenca C, Chiste RC, Fernandes E, Freitas M. 2016. Size-dependent

639 cytotoxicity of silver nanoparticles in human neutrophils assessed by multiple analytical approaches. Life Sciences 145:247-254. DOI: 10.1016/j.1fs.2015.12.046.

641 Svec D, Tichopad A, Novosadova V, Pfaffl MW, Kubista M. 2015. How good is a PCR

642 efficiency estimate: recommendations for precise and robust qPCR efficiency

643 assessments. Biomolecular Detection and Quantification 3:9-16. DOI: 10.1016/j.bdq.2015.01.005.

Taylor SC, Mrkusich EM. 2014. The state of RT-quantitative PCR: firsthand observations of PCR experiments (MIQE). Journal of Molecular Microbiology and Biotechnology 24:4652. DOI: $10.1159 / 000356189$.

Thummabancha K, Onparn N, Srisapoome P. 2016. Analysis of hematologic alterations, immune responses and metallothionein gene expression in Nile tilapia (Oreochromis niloticus) exposed to silver nanoparticles. Journal of Immunotoxicology 3:909-917. DOI:

653 Tizard IR. 2013a. Cell signaling: cytokines and their receptors. In: Tizard IR, ed. Veterinary Immunology. 9th ed. St. Louis: Saunders, 75-83. 
655 Tizard IR. 2013b. Helper T cells and their response to antigen. In: Tizard IR, ed. Veterinary

656 Immunology. 9th ed. St. Louis: Saunders, 137-149.

657 van der Zande M, Vandebriel RJ, Van Doren E, Kramer E, Herrera Rivera Z, Serrano-Rojero

658 CS, Gremmer ER, Mast J, Peters RJ, Hollman PC, Hendriksen PJ, Marvin HJ,

659

660 nanoparticles and silver ions in rats after 28-day oral exposure. ACS Nano 6:7427-7442.

661 DOI: $10.1021 / \mathrm{nn} 302649$ p.

662 Vandesompele J, De Preter K, Pattyn F, Poppe B, Van Roy N, De Paepe A, Speleman F. 2002.

663 Peijnenburg AA, Bouwmeester H. 2012. Distribution, elimination, and toxicity of silver multiple internal control genes. Genome Biology 3:research0034.1-research0034.11.

Veiopoulou C, Kogopoulou O, Tzakos E, Mavrothalassitis G, Mitsias D, Karafoulidou A, human CD4+T cells is differentially regulated by $\mathrm{p} 38$ : mode of stimulation-dependent regulation of IL-2. Neuroimmunomodulation 11:199-208. DOI: 10.1159/000078437.

Walters CR, Pool EJ, Somerset VS. 2014. Ecotoxicity of silver nanomaterials in the aquatic environment: a review of literature and gaps in nano-toxicological research. Journal of Environmental Science and Health. Part A, Toxic/hazardous Substances and Environmental Engineering 49:1588-1601. DOI: 10.1080/10934529.2014.938536. 
673 Wang H, Ho KT, Scheckel KG, Wu F, Cantwell MG, Katz DR, Horowitz DB, Boothman WS,

674 Burgess RM. 2014. Toxicity, bioaccumulation, and biotransformation of silver

675 nanoparticles in marine organisms. Environmental Science and Technology 48:13711-

676 13717. DOI: 10.1021/es502976y.

677 Wang Z, Liu S, Ma J, Qu G, Wang X, Yu S, He J, Liu J, Xia T, Jiang GB. 2013. Silver

678 nanoparticles induced RNA polymerase-silver binding and RNA transcription inhibition

679 in erythroid progenitor cells. ACS Nano 7:4171-4186. DOI: 10.1021/nn400594s.

680 Woshner VM, O'Hara TM, Bratton GR, Suydam RS, Beasley VR. 2001. Concentrations and

681 interactions of selected essential and non-essential elements in bowhead and beluga

682 whales of arctic Alaska. Journal of Wildlife Diseases 37:693-710. DOI: 10.7589/0090-

683

$3558-37.4 .693$ 


\section{Figure 1}

Characterization of C-AgNP ${ }_{20}$.

Representative TEM image of C-AgNP 20 in complete RPMI-1640.

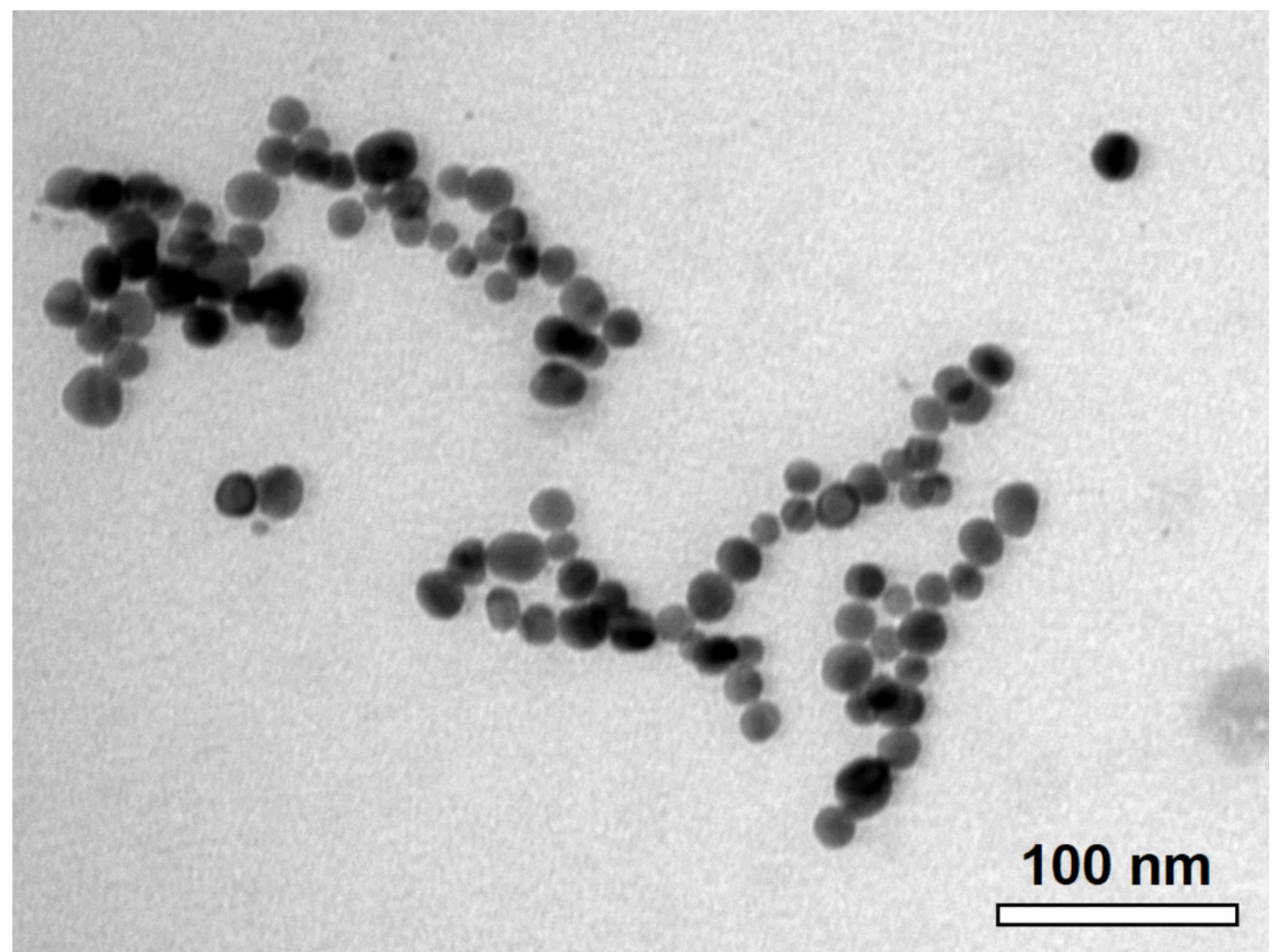




\section{Figure 2}

Cytotoxicity of C-AgNP ${ }_{20}$ on CPBMCs after $24 \mathrm{~h}$ of culture with or without ConA.

(A) Ratio of apoptotic CPBMCs in percentage between treatment and control without ConA.

(B) Ratio of late apoptotic/necrotic CPBMCs in percentage between treatment and control without ConA. (C) Ratio of apoptotic CPBMCs in percentage between treatment and control with ConA. (D) Ratio of late apoptotic/necrotic CPBMCs in percentage between treatment and control with ConA. The bar in the middle of the box represents the median, and the bottom and top of the box describe the first and third quartiles. The whiskers show the $75^{\text {th }}$ percentile plus 1.5 times IQR and $25^{\text {th }}$ percentile minus 1.5 times IQR of all data, and any values that are greater than these are defined as outliers and plotted as individual points. Asterisks indicate statistically significant differences from the control $) p<0.05$, Kruskal-Wallis Test). 

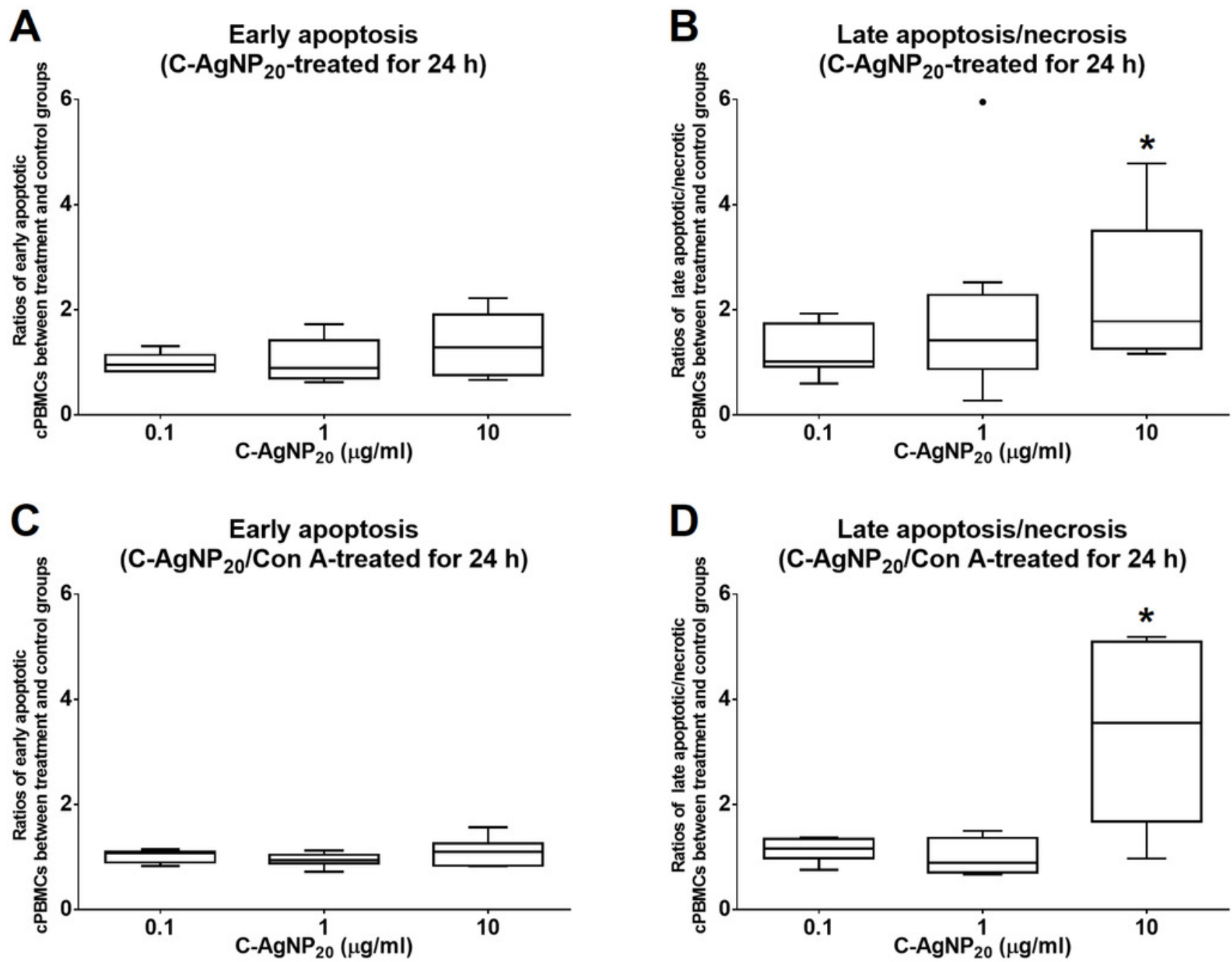


\section{Figure 3}

Time kinetics of mRNA expression levels of (A) IL-2, (B) IL-4, (C) IL-10, (D) IL-12, (E) IFN$\gamma$ and $(F)$ TNF- $\alpha$ of CPBMCs with ConA.

The bar in the middle of the box represents the median, and the bottom and top of the box describe the first and third quartiles. The whiskers show the $75^{\text {th }}$ percentile plus 1.5 times IQR and $25^{\text {th }}$ percentile minus 1.5 times IQR of all data, and any values that are greater than these are defined as outliers and plotted as individual points. Asterisks indicate statistically significant differences from the control $) p<0.05$, Kruskal-Wallis Test). 

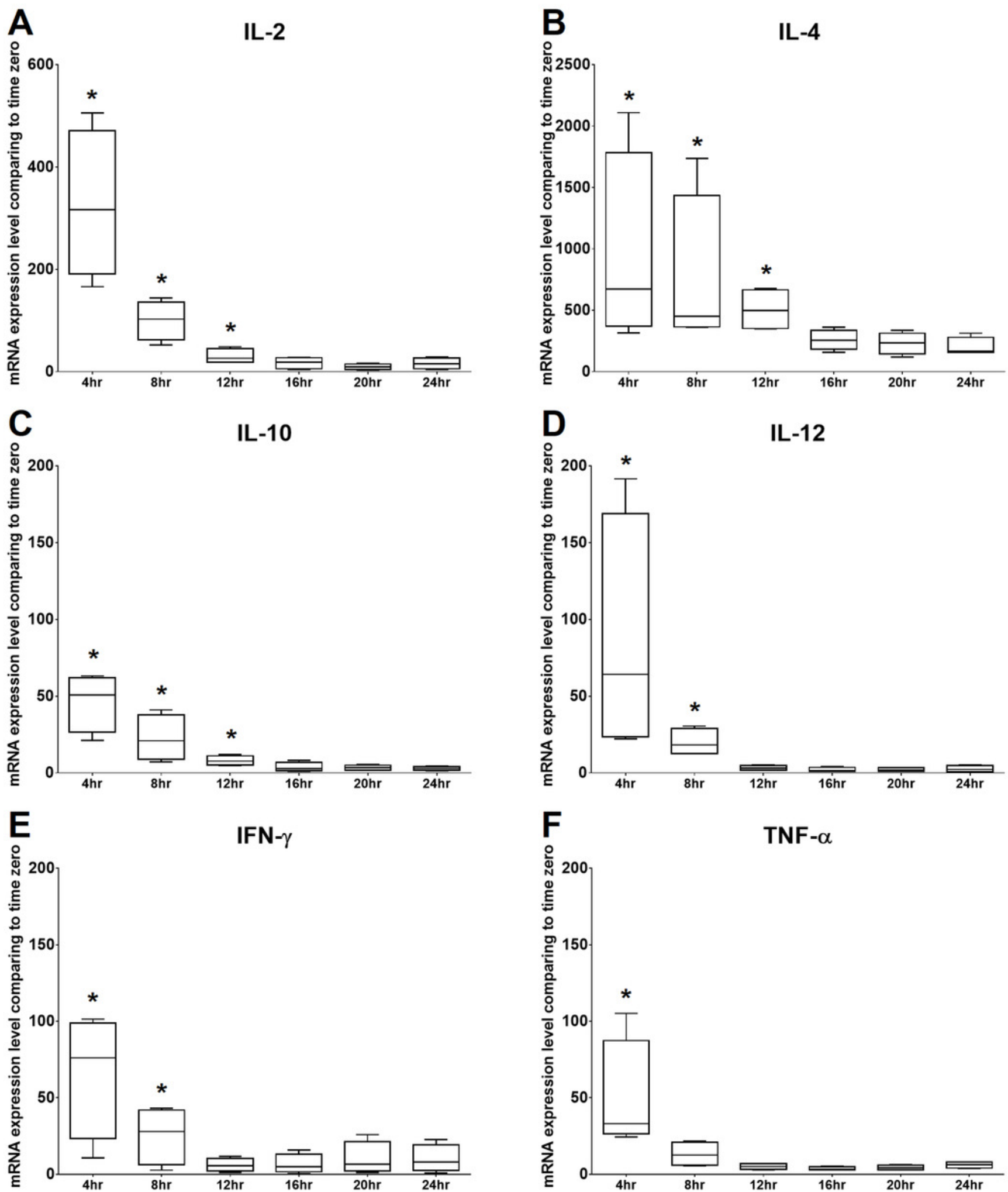


\section{Figure 4}

Effects of C-AgNP ${ }_{20}$ on mRNA expression levels of (A) IL-2, (B) IL-4, (C) IL-10, (D) IL-12, (E) IFN- $\gamma$ and (F) TNF- $\alpha$ of CPBMCs with ConA.

The bar in the middle of the box represents the median, and the bottom and top of the box describe the first and third quartiles. The whiskers show the $75^{\text {th }}$ percentile plus 1.5 times IQR and $25^{\text {th }}$ percentile minus 1.5 times IQR of all data, and any values that are greater than these are defined as outliers and plotted as individual points. Asterisks indicate statistically significant differences from the control $) p<0.05$, Kruskal-Wallis Test). 

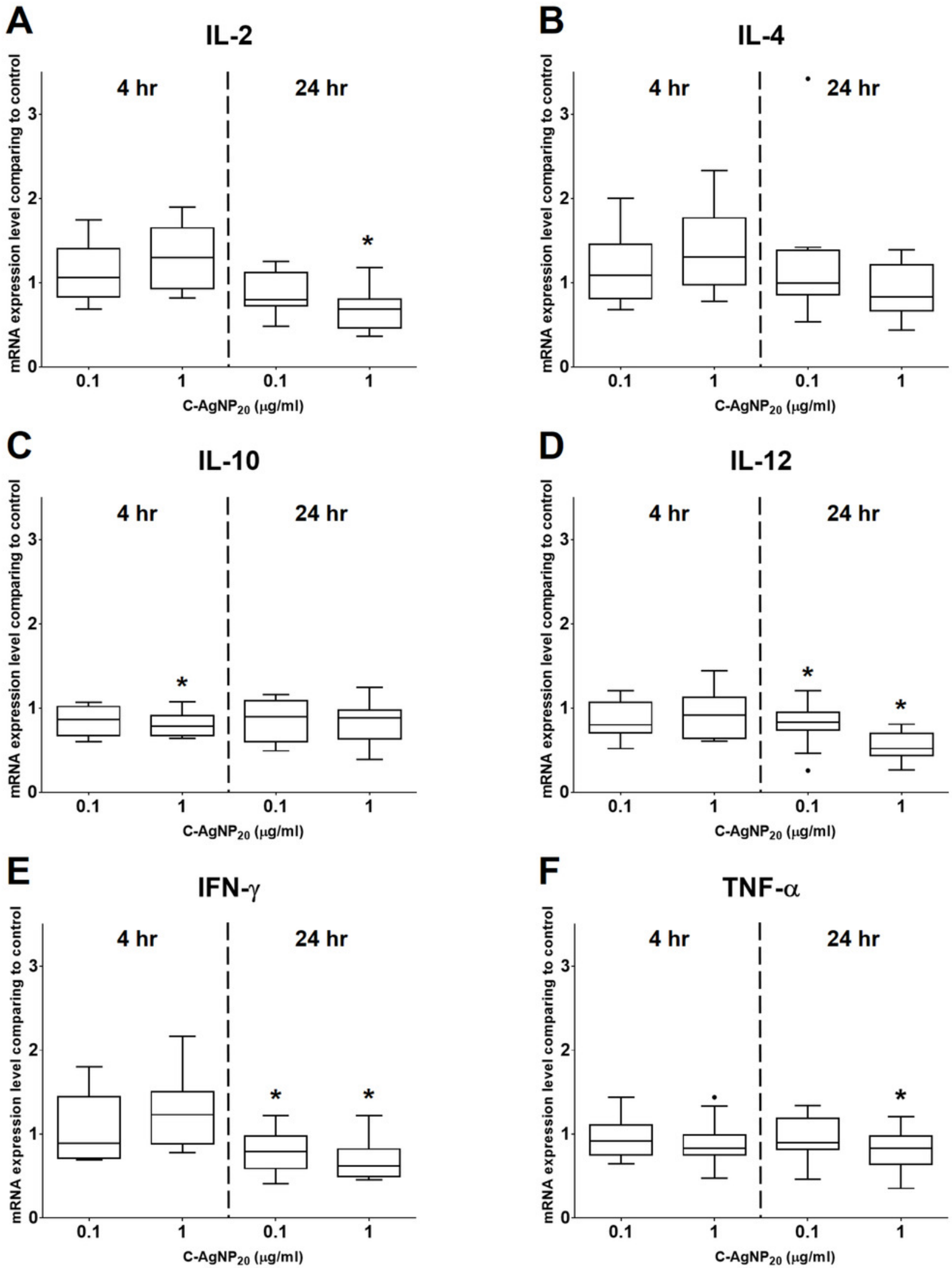
Figure 5

The ratios of Th1 and Th2 polarizing cytokines at 4 and $24 \mathrm{~h}$ of culture.

(A) Ratio of IFN- $\gamma$ and IL-4; (B) Ratio of IL-12 and IL-4. The bar in the middle of the box represents the median, and the bottom and top of the box describe the first and third quartiles. The whiskers show the $75^{\text {th }}$ percentile plus 1.5 times IQR and $25^{\text {th }}$ percentile minus 1.5 times IQR of all data, and any values that are greater than these are defined as outliers and plotted as individual points. Asterisks indicate statistically significant differences from the control $(p<0.05$, Kruskal-Wallis Test).
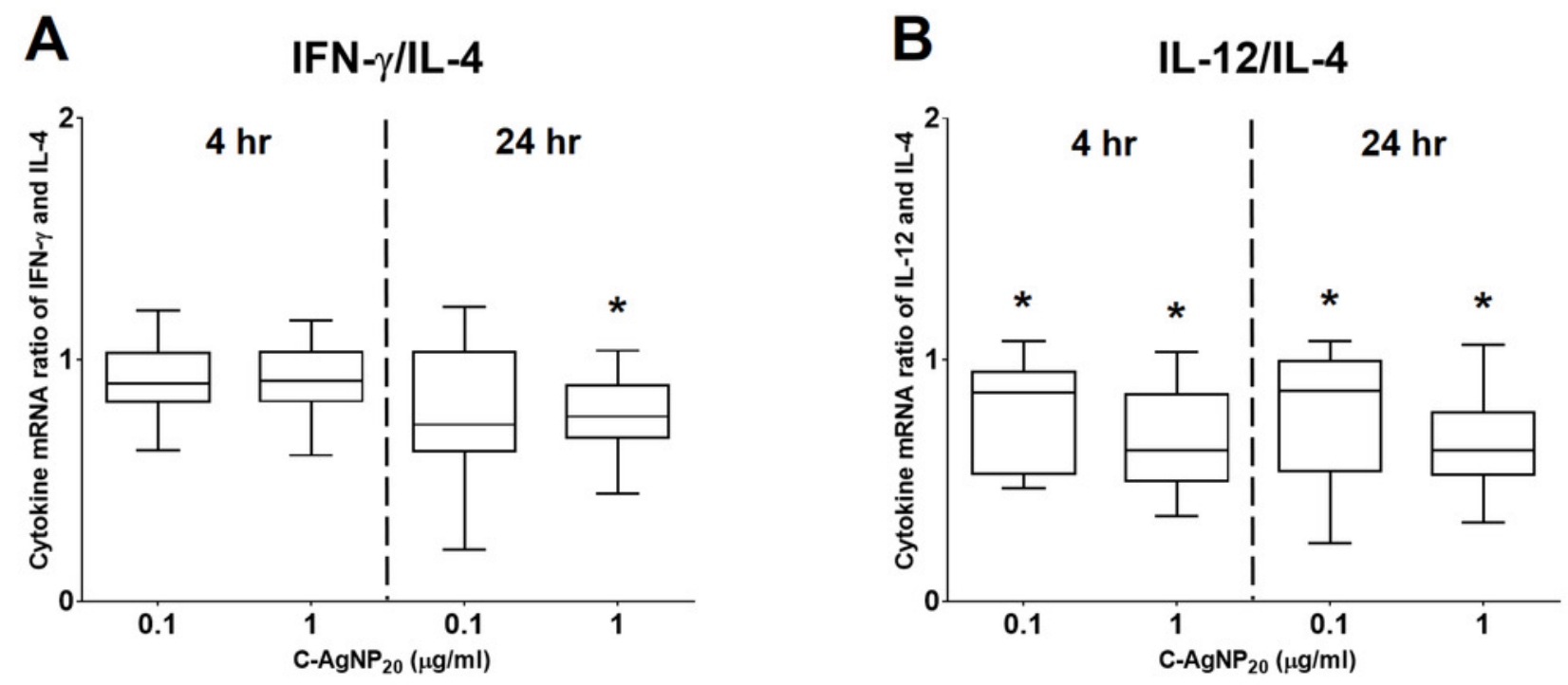


\section{Table $\mathbf{1}$ (on next page)}

The size distribution and zeta potential of the $20 \mathrm{~nm}$ citrate-AgNPs $\left(\mathrm{C}-\mathrm{AgNP}_{20}\right)$. 
1 Table 1. The size distribution and zeta potential of the $20 \mathrm{~nm}$ citrate-AgNPs $\left(\mathrm{C}-\mathrm{AgNP}_{20}\right)$

$\begin{array}{llr}\text { Concentration }(\mu \mathrm{g} / \mathrm{ml}) & 100 & 500\end{array}$

$\begin{array}{lll}\text { Z-Average (nm) } & 26.62 \pm 0.15 & 26.54 \pm 0.08\end{array}$

Size (nm) (intensity) $\quad 30.27 \pm 0.18(100 \%) \quad 29.64 \pm 0.30(100 \%)$

$\begin{array}{lll}\text { Zeta potential }(\mathrm{mV}) & -38.97 \pm 1.33 & -44.2 \pm 1.35\end{array}$

$\begin{array}{lll}\text { PdI } & 0.12 \pm 0.00 & 0.11 \pm 0.01\end{array}$

Results shown are means \pm SD from three different lectures.

$\mathrm{NP}$ were suspended in $2 \mathrm{nM}$ citrate buffer and measurements performed at room temperature.

PdI, Poly-dispersity Index. 
Table 2 (on next page)

Primer sets used in this study and their efficiencies. 
Table 2. Primer sets used in this study and their efficiencies

Gene Accession number Primer sequence(5'-3')

\section{GAPDH DQ404538.1}

B2M DQ404542.1

CACCTCAAGATCGTCAGCAA

GCCGAAGTGGTCATGGAT

GGTGGAGCAATCAGACCTGT

GCGTTGGGAGTGAACTCAG

IL-2 EU638316

IL-4 EU-638315,

IL-10 AB775207

IL-12 EU638319

IFN- $\gamma \quad$ EU638318

TNF- $\alpha \quad$ EU638323

$\begin{array}{lll}\text { Efficiency (\%) } & \mathrm{R}^{2} & \text { Reference } \\ 100.97 & 0.9949 & \text { Chen et al. 2015 } \\ 93.32 & 0.9984 & \text { Chen et al. 2015 } \\ 91.92 & 0.999 & \text { Sitt et al. 2008 } \\ 99.25 & 0.9982 & \text { Sitt et al. 2008 } \\ 93.14 & 0.9986 & \text { Segawa et al. 2013 } \\ 91.08 & 0.9999 & \text { Sitt et al. 2008 } \\ 92.42 & 0.9976 & \text { Sitt et al. 2008 } \\ 101.48 & 0.9934 & \text { Sitt et al. 2008 }\end{array}$

\section{GTGAATCTTGTTTCAGATCCCTTTAG} GGAGCTGCCTGTAGAAGACGTCTTTGC CTTCATTCACAGAACAGGTCATGTTTGCC TGCTGGAGGACTTTAAGGGTTA ATGAAGATGTCAAACTCACTCATG CAGACCAGAGCGATGAGGTCTTG GGGCTCTTTCTGGTCCTTTAAGATA CAGAGCCAAATAGTCTCCTTCTACTTC CTGGATCTGCAGATCATCTACCGGAATTTG GAGGGAAGAGTTCCCAACTGGCTA CTGAGTACTGAGGTTGGCTACAAC 